\title{
Article
}

\section{Equipping Property Graduates for the Digital Age}

\author{
Rotimi Abidoye *(D), Benson Teck Heng Lim, Yu-Cheng Lin and Junge Ma
}

check for

updates

Citation: Abidoye, R.; Lim, B.T.H.; Lin, Y.-C.; Ma, J. Equipping Property Graduates for the Digital Age. Sustainability 2022, 14, 640. https:/ / doi.org/10.3390/su14020640

Academic Editor: Francesco Tajani

Received: 21 November 2021

Accepted: 4 January 2022

Published: 7 January 2022

Publisher's Note: MDPI stays neutral with regard to jurisdictional claims in published maps and institutional affiliations.

Copyright: () 2022 by the authors Licensee MDPI, Basel, Switzerland. This article is an open access article distributed under the terms and conditions of the Creative Commons Attribution (CC BY) license (https:// creativecommons.org/licenses/by/ $4.0 /)$.
School of Built Environment, UNSW Sydney, Sydney, NSW 2052, Australia; b.lim@unsw.edu.au (B.T.H.L.); yu-cheng.lin@unsw.edu.au (Y.-C.L.); junge.ma@unsw.edu.au (J.M.)

* Correspondence: r.abidoye@unsw.edu.au; Tel.: +61-290-657-139

\begin{abstract}
Bridging the gaps between property graduates' attributes and industry expectations has been touted to be the key driver of sustainable development for the next generation of the workforce. This study investigated property-related knowledge and skills from the perspective of property employers and graduates in Australia in the digital age by (1) identifying the most and least important knowledge and skillsets in the property sector; (2) examining the strategies used to develop the required knowledge and skillsets; and (3) ascertaining if there are differences in the knowledge and skillsets perceived to be necessary between employers and graduates. A questionnaire survey was undertaken across property employers affiliated with the Royal Institution of Chartered Surveyors (RICS) and graduates of an Australian university. The results showed that problem solving and time management are the most important knowledge and skills for property employers and graduates, respectively. Notably, there were statistically significant differences in the perceived importance of course directors maintaining close communication with employers, real-life case study-based school assessment, the use of various course delivery methods, inviting guest speakers, and internship training while studying between employers and graduates. This finding implies that Australian property professionals are yet to fully embrace technology in the digital age.
\end{abstract}

Keywords: property; property graduates; knowledge and skills; property employers; Australia

\section{Introduction}

The property sector has long been known as a key driver for the economic growth and social development of any nation [1]. In Australia, the property sector is the biggest contributor to its gross domestic product (GDP) and employment market, creating more than 1.4 million jobs annually [2]. Over the years, a considerable amount of research has documented the key stakeholders of the property industry and their close associations, such as professional (regulatory) bodies, educational institutions, property professionals, government, and property firms [3]. For example, educational service providers will design relevant property-related curriculum to help in educating and nurturing students with the essential skillsets and getting them job-ready for the property sector, while property graduates apply these skillsets at work and, in turn, help maintain and improve the viability of property firms [4-6]. Thereafter, property firms need to assess the performance of their graduate employees and offer relevant training and development programs. It follows that as Van de Ven and Johnson [7] suggested, there is a constant call for stronger collaboration between academics and industry practitioners to reduce the expectation gaps and improve the job readiness of graduates.

Hitherto, many studies have reported the expectation gaps between property graduates and the property employers across different countries such as the USA [8-14], the UK [8,9,12,15,16], China [4], Hong Kong [9], South Africa [17], Nigeria [18], New Zealand [19], and Australia [9,12,20-23].

Hypothetically, these expectation gaps could be widened in the prevailing era of digital and technological advancement in both academia and industry circles. Educational data 
science (EDS) has played a significant role in the use of computer science, education, statistics, big data analytics (e.g., artificial intelligence (AI), machine learning, natural language processing), and other social sciences to ascertain social and technical phenomena [24]. Thus, there is a collective and louder voice for changes in property course curricula in response to changes in businesses and the property industry [12]. However, little or no comparable work has been undertaken to update and provide information about the gaps between the skills of property graduates and employers' expectations. It is thus not known what the gaps are and how expectations and perceptions may vary between graduates and employers, which raises the following questions:

1. Do the skills and knowledge of property graduates meet property industry employers' expectations in this digital age?

2. What series of skills do property employers expect property graduates to possess in this digital age?

3. What are the best strategies that can equip property graduates with the knowledge and skills required to excel in practice?

In addressing the gaps and questions above, this project aims to investigate the perception of graduates and employers regarding the essential knowledge and skillsets for the property industry in this digital age. With this aim, the specific objectives are to (1) identify the most and least important knowledge and skillsets, (2) examine the strategies used to develop relevant knowledge and skillsets, and (3) ascertain if there are significant differences in the perceived importance of those knowledge and skillsets between graduates and employers. These objectives are important because they will help to inform academics of the expectation gaps and in turn enable them to update their curricula and configure and implement more targeted training and development courses for students in order to improve their job readiness.

\section{Literature Review}

\subsection{Essential Knowledge and Skills for the Property Industry}

Unlike most industries, the property industry is a complex one that covers many different subjects and does not have a clearly defined body of knowledge [25]. Over the past two decades, numerous studies have documented the knowledge and skills required by industry practice $[19,23,26,27]$ and the employability of property/real estate graduates [28-31]. Table 1 summarises a total of 45 pieces of knowledge and skills extracted from previous studies.

Table 1. The studies on property industry knowledge and skills.

\begin{tabular}{lll}
\hline Item Code & Items & Sources \\
\hline KS1 & Property valuation & $\begin{array}{l}\text { Newell and Eves [5]; Black and Rabianski [25]; Hoxley, Poon [32]; } \\
\text { Poon [33]; Ayodele, Oladokun [31] }\end{array}$ \\
KS2 & Property laws/regulations & $\begin{array}{l}\text { Blake and Susilawati [22]; Blake, Cradduck [34]; Hoxley, Poon [32]; } \\
\text { Poon [33]; Ayodele, Oladokun [31] }\end{array}$ \\
& & Black and Rabianski [25]; Alao, Pilane [35]; Hoxley, Poon [32]; \\
KS3 & Professional ethics & Ayodele, Oladokun [31], Matsouka and Mihail [36]; Obi, Hampton [37]; \\
KS4 & Customer service & Hoxley, Poon [32]; Poon [33]; [14], Succi and Canovi [27] \\
KS5 & Feasibility study & Black and Rabianski [25] \\
KS6 & Due diligence & Gibler, Black [9]; Epley [10]; Manning and Epley [13] \\
KS7 & Town planning & Callanan and McCarthy [19]; Poon [33]; Ayodele, Oladokun [31] \\
KS8 & Property economics & Newell and Eves [5]; Callanan and McCarthy [19]; Hoxley, Poon [32] \\
KS9 & Finance and accounting & Manning and Epley [13]; Hoxley, Poon [32]; Poon [33]; \\
KS10 & Investment & Ayodele, Oladokun [31] \\
KS11 & Risk management & Manning and Epley [13]; Poon [33] \\
& & Black and Rabianski [25]; Weinstein and Worzala [14]; \\
\hline
\end{tabular}


Table 1. Cont.

\begin{tabular}{|c|c|c|}
\hline Item Code & Items & Sources \\
\hline KS12 & $\begin{array}{l}\text { Health, safety \& environment } \\
\text { management. }\end{array}$ & Hoxley, Poon [32]; Poon [33] \\
\hline KS13 & Asset management & Hoxley, Poon [32]; Poon [33] \\
\hline KS14 & Research and analysis methods & $\begin{array}{l}\text { Callanan and McCarthy [19]; Epley [10]; Alao, Pilane [35]; Aliu and } \\
\text { Aigbavboa [28], Jackson and Chapman [38] Obi, Hampton [37] }\end{array}$ \\
\hline KS15 & Data management & Hoxley, Poon [32]; Poon [33]; Prikshat, Montague [39] \\
\hline KS16 & Sustainability & Savage [40]; Poon [33]; Gallardo-Vázquez and Folgado-Fernández [41] \\
\hline KS17 & Urban renewal & Savage [40]; Hoxley, Poon [32]; Poon [33] \\
\hline KS18 & Environment impact assessment & Savage [40]; Hoxley, Poon [32]; Poon [33] \\
\hline KS19 & Machine Learning & Pate [42]; Prikshat, Montague [39]; Starr, Saginor [43] \\
\hline KS20 & Artificial Intelligence & Pate [42]; Prikshat, Montague [39]; Starr, Saginor [43] \\
\hline KS21 & Big Data Analysis & Pate [42]; Starr, Saginor [43] \\
\hline KS22 & Blockchain & Baum [44]; Pate [42] \\
\hline KS23 & Sharing Economy & Baum [44] \\
\hline KS24 & Smart Building/City & Baum [44]; Starr, Saginor [43] \\
\hline KS25 & Real Estate FinTech & Baum [44]; Starr, Saginor [43] \\
\hline KS26 & ConTech & Baum [44] \\
\hline KS27 & Marketing and sales & Gibler, Black [9]; Epley [10]; Poon [33]; Matsouka and Mihail [36]; Pate [42] \\
\hline KS28 & Effective oral communication & $\begin{array}{l}\text { Weinstein and Worzala [14]; Xiao and Chan [4]; Ayodele, Oladokun [31]; } \\
\text { Obi, Hampton [37]; Azmi, Hashim [45]; Succi and Canovi [27] }\end{array}$ \\
\hline KS29 & Effective written communication & $\begin{array}{l}\text { Weinstein and Worzala [14]; Poon [33]; Xiao and Chan [4]; } \\
\text { Ayodele, Oladokun [31]; Azmi, Hashim [45]; Succi and Canovi [27] }\end{array}$ \\
\hline KS30 & Report writing & Callanan and McCarthy [19]; Poon [46]; Xiao and Chan [4] \\
\hline KS31 & Numeracy & $\begin{array}{l}\text { Newell and Mallik [47]; Poon [33]; Prikshat, Montague [39]; } \\
\text { Obi, Hampton [37] }\end{array}$ \\
\hline KS32 & Problem solving & Alao, Pilane [35]; Aliu and Aigbavboa [28] \\
\hline KS33 & Negotiation & $\begin{array}{l}\text { Black and Rabianski [25]; Poon [33]; Prikshat, Montague [39]; } \\
\text { Obi, Hampton [37] }\end{array}$ \\
\hline KS34 & Time management & Alao, Pilane [35]; Poon [33]; Ayodele, Oladokun [31] \\
\hline KS35 & Critical thinking & $\begin{array}{l}\text { Gibler, Black [9]; Weinstein and Worzala [14]; Alao, Pilane [35]; } \\
\text { Reid and Anderson [48]; Poon [33] }\end{array}$ \\
\hline KS36 & Microsoft Office Suite & Alao, Pilane [35]; Azmi, Hashim [45]; Prikshat, Montague [39] \\
\hline KS37 & Industry-based software & Weinstein and Worzala [14]; Poon [33]; Obi, Hampton [37] \\
\hline KS38 & Ability to work in a team & $\begin{array}{l}\text { Weinstein and Worzala [14]; Poon [33]; Matsouka and Mihail [36]; } \\
\text { Pate [42]; Obi, Hampton [37]; Succi and Canovi [27] }\end{array}$ \\
\hline KS39 & Ability to work independently & Hoxley, Poon [32]; Poon [33]; Azmi, Hashim [45] \\
\hline KS40 & Self-confidence & Hoxley, Poon [32]; Poon [33]; Azmi, Hashim [45] \\
\hline KS41 & Innovation & $\begin{array}{l}\text { Hoxley, Poon [32]; Matsouka and Mihail [36]; Azmi, Hashim [45]; } \\
\text { Succi and Canovi [27] }\end{array}$ \\
\hline KS42 & Leadership & $\begin{array}{l}\text { Weinstein and Worzala [14]; Alao, Pilane [35]; Ahn, Annie [49]; } \\
\text { Ayodele, Oladokun [31]; Obi, Hampton [37] }\end{array}$ \\
\hline KS43 & Creativity & $\begin{array}{l}\text { Hoxley, Poon [32]; Matsouka and Mihail [36]; Azmi, Hashim [45]; } \\
\text { Pate [42]; Obi, Hampton [37]; Succi and Canovi [27] }\end{array}$ \\
\hline KS44 & Adaptability & $\begin{array}{l}\text { Alao, Pilane [35]; Matsouka and Mihail [36], Azmi, Hashim [45]; } \\
\text { Succi and Canovi [27]; Pate [42]; Aliu and Aigbavboa [28] }\end{array}$ \\
\hline KS45 & Emotional intelligence & Matsouka and Mihail [36]; Pate [42]; Obi, Hampton [37] \\
\hline \multicolumn{3}{|c|}{ Initiatives for Bridging the Expectation Gaps } \\
\hline S1 & On-the-job training after graduation & Ndong de Souza [50] \\
\hline S2 & $\begin{array}{l}\text { Overhauling of university's } \\
\text { curriculum }\end{array}$ & Poon [33], Odubiyi, Aghimien [51] \\
\hline S3 & $\begin{array}{l}\text { Encouraging students to join } \\
\text { professional organisations }\end{array}$ & Poon [33] \\
\hline S4 & $\begin{array}{l}\text { Course directors maintaining close } \\
\text { communication with employers }\end{array}$ & Poon [33] \\
\hline S5 & $\begin{array}{l}\text { Using various course delivery } \\
\text { methods such as simulation }\end{array}$ & Avramenko [52], Poon [33] \\
\hline
\end{tabular}


Table 1. Cont.

\begin{tabular}{lll}
\hline Item Code & Items & Sources \\
\hline S6 & $\begin{array}{l}\text { School assessment should be based } \\
\text { on real-life case studies }\end{array}$ & Wong, Wong [53] \\
S7 & $\begin{array}{l}\text { Industry practitioners guest lecture } \\
\text { presentation to students }\end{array}$ & Callanan and McCarthy [19], Odubiyi, Aghimien [51] \\
S8 & $\begin{array}{l}\text { Compulsory internship training } \\
\text { while studying }\end{array}$ & Callanan and McCarthy [19] \\
S9 & Attending CPD as students & Scheurwater [54], Hoxley, Poon [32], Succi and Canovi [27] \\
\hline
\end{tabular}

Note: Knowledge and Skills means KS.

\subsection{Gaps between Property Practice and Property Education}

Despite the ongoing call for bridging the gap between students' attributes and competence expectations in the industry, little has been done to explore property employers' expectations of their graduate employees. For example, Gibler, Black [9] surveyed property professionals across the USA, the UK, Australia, and Hong Kong and found that strategic planning, negotiation, business, property portfolio management, and deal-making skills are the most vital competencies. Their findings, however, reveal that tax management, international finance/economics, and foreign languages are the least important skillsets. Interestingly, these findings tend to agree with those of Epley [10] in that the most significant areas are development, decision making, leasing, management, real estate finance, acquisitions, and sales, as well as that, at an executive level, general analysis, market interpretation, and people skills are seen as key concepts and skills. Around the same time, Galuppo and Worzala [11] surveyed property employers and graduates in the USA and found communication skills and financial skills to be the most important, with the least important skills being with technology and statistics. It was reported that property employers expect graduates to gain project-based experience, whilst graduates indicated a preference for experiencing diversified curricula in school. Based on their interviews of educators, administrators, and practitioners from the USA property market, Weinstein and Worzala [14] recommended that a successful curriculum for graduates should include knowledge and skills such as oral and written communication, negotiation, risk analysis, critical thinking, decision making, social and ethical responsibility, the use of technology, problem solving, and leadership. Their findings tend to add weight to the conclusion of Manning and Epley [13], who stated that the competencies and skills required by corporate property employers are deficient in US property courses.

Oladokun's [18] survey of real estate students and professionals in Nigeria showed that the most vital skills were investment in corporate strategy, productivity, customer and employee management, financial performance, and space efficiency management. In contrast, the least important skill was found to be portfolio efficiency. In the context of the New Zealand's property appraisal industry, Callanan and McCarthy [19] surveyed both property employers and graduates and found that property employers acknowledged the graduates' computer, communication, and analytical skills but criticised their practical knowledge and skills, such as building construction and property development. Their recommendation for property appraisal courses is to integrate the use of case studies, work experience, and on-site training. In China, Xiao and Chan [4] discovered that international banks and investors showed slight interest in giving opportunities to local property valuation firms due to capacity issues and language barriers. The circumstances showed that there is a significant gap between local property appraisal education and the professional competence required by local and international banks and investors. Thus, the authors recommended that local property appraisal education providers should raise the competences of property appraisal courses at an international level through a collaboration with cross-country property education programs.

In Australia, Poon [33] utilised 21 attributes, 20 skills, and 31 knowledge areas to explore the gap between the skills property graduates acquired in school and the competence 
expectations of employers. It was found that the most important attributes, skills, and knowledge areas were practical experience, effective written communication, and rural valuation skills, while international property knowledge, creativity, and having a second language were less important areas. Warren and Heng [12] conducted a systematic review of academic curricula and professional development frameworks across the USA, the UK, and Australia and showed that there was a gap between the skills students acquired in school and the competence expectations in the industry. They thus urged for a stronger collaboration between academia and professional bodies in order to bridge the expectation gaps and improve the job readiness of students. Given the impacts of increasing globalisation and technological advancement on property education, Shi-Ming [8] posited that more interactive teaching and learning styles should be included in property courses in order to develop students' teamwork, interpersonal and communication skills, and analytical and critical thinking skills.

This challenge is not only peculiar to the property profession but also experienced in other built environment professions. For instance, regarding the Quantity Survey (QS) profession, Wong, Wong [53] stated that the QS education in Hong Kong could not meet the needs of modern development due to the ever-changing construction industry and outdated program curricula. In South Africa, Ndong de Souza [50] found that the employers had to train QS graduates on the job as they were not well equipped for the workplace; a plausible reason for this is that QS students are not introduced to new competencies that are emerging in the industry. Yogeshwaran, Perera [55] found that 20 out of 30 competencies of QS graduates are below the industry expectations. This tends to add weight to the conclusion of Odubiyi, Aghimien [51] in that some root causes of the expectation gaps between students' skills and industry expectations are the theory-driven design and nature of courses, inadequate curricula, and the slow adoption of innovations.

In summary, this section identifies a gap between the skills and knowledge students acquire in school and the industry competence expectations. Although this peculiar issue has been investigated by property and built environment studies across the USA, the UK, China, Hong Kong, South Africa, Nigeria, New Zealand, and Australia, stronger collaboration between academia and professionals and more interactive teaching and learning styles have been suggested to bridge expectation gaps between these two groups (graduates and employers) by international scholars. Importantly, little or no comparable studies have been conducted to investigate this issue in the digital age. Thus, this study investigates the perceptions of graduates and employers regarding the essential skills and knowledge needed in the property industry in this digital age.

\subsection{Initiatives for Bridging the Expectation Gaps}

Over the past two decades, attempts to address the gap between the knowledge and skills property students obtain from school and employers' expectations have been proposed (see Table 1 for a list of strategies). For example, Callanan and McCarthy [19] documented the practicum paper introduced by the Massey University, New Zealand, aimed at providing students with a creditable time for industrial practices and involving industry practitioners in delivering lectures to students. They believe the stronger collaboration with industry leaders regarding providing workshops and seminars would be very helpful to students' thought and career development. This tends to support the arguments of Odubiyi, Aghimien [51] and Wong, Wong [53], who stated that organising regular industry-related lectures, seminars, and workshops and including real-life case studies are the best practices for helping to bridge the gap between QS academics and practice and improving students' job readiness.

In support of the above, Avramenko [52] further proposed the use of real-life business simulation for helping students to be aware of the reality and learn from their mistakes, thereby helping them to become job ready while appreciating the relevant theories. Poon [33] seconded this and pointed out that close communication and collaboration between employers, professional bodies, and academics are the antecedents of effective course 
design and learning. Poon [33] added that great emphasis should be placed on encouraging students or graduates to become members of relevant professional bodies and be involved in social events and Continuing Professional Development (CPD) programs. With regard to this, Scheurwater [54]; Hoxley, Poon [32]; and Succi and Canovi [27] shared that, like many other professions, property valuation practice has been considerably impacted by the rapid advance of technologies and methodologies and changes in societal expectations. Thus, through CPD and other self-development programs, property professionals could improve their commercial awareness and technology acumen, thus making them more viable in the changing business environment.

\section{Materials and Methods}

This research is exploratory and adopted a quantitative research approach using an online questionnaire survey. The online questionnaire survey was adopted because it removes the physical geographic barriers, increases the width of survey distribution, offers anonymity, and is more cost-effective to administer. More importantly, it could be best-suited to the targeted respondents, who are busy practitioners, allowing them to complete the questionnaire based on their availability and preference [56,57]. The survey was conducted using an online questionnaire survey designed based on the University of New South Wales (UNSW) Qualtrics survey platform. The online questionnaire approach has been adopted in previous studies, such as those of Callanan and McCarthy [19], TorresMachí, Carrión [29], Poon [33], and Aliu and Aigbavboa [28] and has been proven to be effective in capturing the opinions of respondents.

In this research, two groups of respondents were targeted-i.e., property employers and graduates. For the former, a sample frame was generated based on the database of the Royal Institution of Chartered Surveyors (RICS), which is one of the leading professional bodies for cost management and property professionals. Following checking and filtering processes, a total of 745 property surveying corporate members were identified and their email addresses were extracted. However, some email messages bounced back, with automatic replies about individuals being on long leave and having changed roles being received. Additionally, replies about businesses being sold and companies not employing property graduates lately were also received. In the end, it was estimated that the invitation reached 654 respondents. In terms of property graduates, students who graduated from the Bachelor of Construction Management and Property and the postgraduate program of Master of Property and Development at UNSW between 2016 and 2020 (five years) were targeted. As a screening process for eligible respondents, a filtering question asking if participants were currently working or had worked in the property industry was included in the questionnaire. For this, two sets of comparable questionnaires were specifically developed.

The questionnaire for property employers contained four sections. The first section required employer respondents to provide background information, such as age, gender, years of industry of experience, education level area of specialisation, and number of graduates hired each year. Thereafter, the respondents were required to rate the importance of 45 knowledge and skill items on a 5-point Likert scale, ranging from 1 'not important' to 5 'extremely important' (see Table 1 for the list of 45 items). This was followed by assessing the knowledge and skills of their graduate employees on a 4-point Likert scale, ranging from 1 'very disappointing' to 4 'above expectation'. In the fourth section, they were required to rate their perception of the feasibility of nine statements concerning the strategies used for improving and developing the practical knowledge and skills of graduate employees during this digital age on a 5-point Likert Scale, ranging from 1 'strongly disagree' to 5 'strongly agree'. Lastly, two open-ended questions were included to allow respondents to share additional knowledge and skills, as well as developmental strategies that were not included in the questionnaire. This provided the researchers with richer qualitative data that could be used to inform the results.

Turning to the structured questionnaire used for graduate respondents to allow for comparative analysis, they were asked to answer similar questions apart from the first and 
third sections. For the former, the graduate respondents were required to provide personal information, such as their highest educational qualification, age, gender, years of industry experience, and current specialisation. In the third section, they were asked to rate the extent to which those 45 identified knowledge and skills had been developed and acquired during their university study on a 5-point Likert scale ranging from 1 ' $<20 \%$ ', 2 '20-39\%', 3 ' $40-59 \%$ ', 4 ' $60-79 \%$ ', to 5 '>79\%'. The two structure survey questionnaires were pilot tested and necessary amendments were made before the wider surveys were conducted.

For the surveys, the simple random sampling method was adopted, whereby initial email invitations were sent to the targeted respondents who were provided with the survey link, where the research aim was further explained, and the participants were assured of the questionnaire's anonymity and confidentiality. Generally, the invitations were sent to employer respondents via their email addresses, which had been extracted from the RICS database, while the graduate respondents were contacted via the UNSW's School administration office. To increase the response rate, a reminder email was sent two weeks after the initial invite. Overall, a total of 43 and 63 responses were obtained from employer and graduate respondents, respectively. Of these, 7 and 27 responses, respectively, were incomplete, thus providing the final sample of 36 each that were suitable for the analysis. Tables 2 and 3 summarise the demographics of the employer and graduate respondents, respectively.

Table 2. Profiles of the property employers.

\begin{tabular}{|c|c|c|}
\hline Variables & Frequency $(n=36)$ & Percentage \\
\hline \multicolumn{3}{|l|}{ Age } \\
\hline 25 and below & 0 & 0.0 \\
\hline $26-30$ & 1 & 2.8 \\
\hline $31-35$ & 4 & 11.1 \\
\hline $36-40$ & 8 & 22.2 \\
\hline $41-45$ & 4 & 11.1 \\
\hline $46-50$ & 4 & 11.1 \\
\hline $51-55$ & 3 & 8.3 \\
\hline 56 and above & 12 & 33.3 \\
\hline \multicolumn{3}{|l|}{ Gender } \\
\hline Male & 31 & 86.1 \\
\hline Female & 5 & 13.9 \\
\hline \multicolumn{3}{|l|}{ Industry experience } \\
\hline $0-5$ years & 0 & 0.0 \\
\hline $6-10$ years & 1 & 2.8 \\
\hline $11-15$ years & 6 & 16.7 \\
\hline 16-20 years & 9 & 25.0 \\
\hline Above 20 years & 20 & 55.6 \\
\hline \multicolumn{3}{|l|}{ Education qualification } \\
\hline Diploma & 1 & 2.8 \\
\hline Bachelor & 22 & 61.1 \\
\hline Master & 10 & 27.8 \\
\hline PhD & 0 & 0.0 \\
\hline Others & 3 & 8.3 \\
\hline \multicolumn{3}{|l|}{ Property graduates hired each year } \\
\hline $1-10$ & 3 & 8.3 \\
\hline $11-50$ & 25 & 69.4 \\
\hline $51-100$ & 7 & 19.4 \\
\hline Above 100 & 1 & 2.8 \\
\hline \multicolumn{3}{|l|}{ Property specialisations * } \\
\hline Property consultancy and analysis & 16 & 22.2 \\
\hline Property valuation & 14 & 19.4 \\
\hline Asset/facility management & 11 & 15.2 \\
\hline Property development & 6 & 8.3 \\
\hline Property sales, leasing and management & 4 & 5.6 \\
\hline Others & 21 & 29.1 \\
\hline
\end{tabular}

*NB: respondents could select more than one option here. Hence, $\mathrm{n}$ is $>36$. 
Table 3. Profiles of the property graduates.

\begin{tabular}{ccc}
\hline Variables & Frequency $(\mathbf{n}=\mathbf{3 6})$ & Percentage \\
\hline Educational qualification & & \\
Undergraduate & 22 & 61.1 \\
Postgraduate & 14 & 38.9 \\
Age & & \\
$20-25$ & 13 & 36.1 \\
$26-30$ & 14 & 38.9 \\
$31-35$ & 8 & 22.2 \\
Above 35 & 1 & 2.8 \\
Gender & & \\
Male & 25 & 69.4 \\
Female & 11 & 30.6 \\
Industry experience & & 22.2 \\
1 year & 8 & 11.1 \\
2 years & 4 & 19.4 \\
3 years & 7 & 5.6 \\
4 years & 2 & 2.8 \\
5 years & 1 & 38.9 \\
Above 5 years & 14 & \\
Property specialisations & & 27.8 \\
Construction project management & 15 & 13.0 \\
Property development & 7 & 11.1 \\
Construction & 6 & 11.1 \\
Contract management & 6 & 27.3 \\
\hline Property consultancy and analysis & 5 & \\
Others & 15 & \\
\hline
\end{tabular}

${ }^{*}$ Note that the respondents could select more than one option here. Hence, $\mathrm{n}$ is $>36$.

The low response rates recorded in this study could be attributed to the COVID-19 lockdown restrictions in place in major cities in Australia (Sydney and Melbourne) during the data collection period. This resulted in many people working from home, with some having to provide home-schooling at the same time (and taking care of any toddlers). These factors put more pressure on many Australians and obviously could have made them disregard any survey invitation. Additionally, as posited by Akintoye and Fitzgerald [58], the low response rates recorded in this study are common in built environment research, and meaningful inferences can be drawn from the results based on the following: (1) for quantitative research, a sample size that is above 30 is graded as large [59]; (2) previous studies have recorded lower responses-examples are Finlay and Tyler [60], Abidoye and Chan [61], and Effiong [62]; (3) a similar study conducted by Steinmetz, Thompson [63] on UNSW Built Environment Students yielded only 24 responses, out of which 6 were invalid. Additionally, a similar study conducted by Warren-Myers and Cradduck [64] on property professionals in Australia received only 21 valid responses. Lastly, according to Hill [65], it is better when research is conducted and data are collected to provide insights about the research problem, and valuable information would not be available if no research was conducted or there was an insistence of a large sample size being used. The Statistical Package for Social Science (SPSS) software was employed to undertake various statistical tests. The test results show that all measurement items had kurtosis and skewness values ranging from -1.302 to 6.815 and -2.430 to 1.238 , respectively. Furthermore, the Kolmogorov-Smirnov test results showed that all items were significant at $p<0.05$. These collectively indicated that the data were not normally distributed and that non-parametric tests should be undertaken.

In this study, Wilcoxon-signed rank (WSR) and Mann-Whitney U (MWU) tests were conducted. Of these, the former was conducted to determine if the median values of the sample were significantly different to the test median value of 3 (i.e., the midpoint of the five-point Likert scale). This would help to inform us of whether there was a significant consensus among the respective groups of respondents regarding these 45 knowledge 
areas and skills, and 9 strategies are summarised in Table 1. Next, the Mann-Whitney $\mathrm{U}(\mathrm{MU})$ test was conducted to determine if there were significant differences in these 54 measurement items between employers and graduates. To gain further insights into the most and least important knowledge areas and skills and the prevalence of these nine strategies, the relative indexing method (RI) was performed and used preferentially to the arithmetic averaging method because the former could enable researchers to compute the relative indices of each item within the range of 0-1 using Equation (1), and in turn allow them to undertake relative comparisons of items between the two groups (following the techniques proposed by Loosemore and Lim [66] and Loosemore, Lim [67]).

$$
\text { Relative Index }(\mathrm{RI})=\frac{\sum_{\mathrm{i}=1}^{\mathrm{n}}\left(\mathrm{i} \times \text { Frequency }_{\mathrm{i}}\right)}{\text { Total number of samples } \times \text { Maximum rating }^{\text {Mamum }}}
$$

where $\mathrm{i}$ and $\mathrm{n}$ represent the smallest (1) and largest (5) points in the 5-point Likert scale, respectively. "Frequency" is the number of respondents who provided the ratings, while the "maximum rating" is the highest point that can be given by the respondents-i.e., 5 . The RI of respective items will range from $0-1$. The higher the RI is, the higher the perceived importance or prevalence of the respective items will be. To facilitate the interpretation of the RI, Akadiri's [68] five categories of RI were adopted: high ' $0.8 \leq \mathrm{RI} \leq 1$ ', high-medium '0.6 $\leq \mathrm{RI}<0.8$ ', medium '0.4 $\leq \mathrm{RI}<0.6^{\prime}$ ', medium-low '0.2 $\leq \mathrm{RI}<0.4^{\prime}$ ', and low / unimportant $` 0 \leq \mathrm{RI}<0.2^{\prime}$.

\section{Results and Discussion}

\subsection{Profile of the Property Employers}

Table 2 shows the profile of the property employers. About $36.1 \%$ of the respondents were less than 40 years old, while $63.9 \%$ of the respondents were 41 years old and above. A closer look at this age distribution shows that one third (33.3\%) of the property professions were above 56 years of age. This echoes the ageing property professional membership that has been noted in previous studies in Australia and overseas, see [69,70]. Nevertheless, this is consistent with the industry experience results, in which $55.6 \%$ of the respondents had more than 20 years of industry experience (see Table 2). In terms of the gender distribution of the respondents, the majority were males $(86.1 \%)$, whilst $13.9 \%$ of them were female.

Regarding the respondents' highest education qualification, $61.1 \%$ of the respondents had a bachelor's degree and $27.8 \%$ of them had a Master's degree (see Table 2). Meanwhile, Table 2 shows that one respondent had a diploma certificate and three respondents had other degrees, such as a postgraduate diploma certificate.

Regarding the number of property graduates hired each year, nearly $70 \%$ of the respondents hired 11-50 property graduates each year. Simultaneously, almost 20\% of our respondents hired 51-100 property graduates, and 2.8\% of them hired more than 100 property graduates each year. However, only $8.3 \%$ of the respondents only hired 1-10 property graduates.

Regarding the property employers' specialisations, the top five ranked property specialisations of the property employers are presented in Table 2. Property consultancy and analysis was the top property specialisation, followed by property valuation, asset/facility management, property development and property sales, and leasing and management. Other specialisations were held by $34.8 \%$ of the sample, and they included fund management, contract management, and estimating.

\subsection{Knowledge and Skills in the Digital Age for the Property Employers}

Figure 1 summarises the perceived importance of knowledge and skills (KS) (based on RI) to the employer respondents. The WRS tests revealed that 34 out of the $45 \mathrm{KS}$ items were significant at $p<0.05$, thus suggesting that there were general consensuses regarding the importance of those items among employers. To the other end, it is notable that most of the $11 \mathrm{KS}$ items (apart from KS6 and KS28) deemed to be statistically insignificant could be broadly related to employees' knowledge bases. The 11 items included KS1 
'Property valuation', KS2 'Property law', KS5 'Feasibility study', KS6 'Due diligence', KS10 'Investment', KS11 'Risk management', KS13 'Asset management', KS14 'Research and analysis methods', KS17 'Urban renewal', KS22 'blockchain', and KS28 'Effective oral communication'. This means that these items were not collectively perceived as important knowledge by employer respondents. This tends to contradict the survey findings of Ayodele, Oladokun [31] and Poon, Hoxley [71], in that valuation, property management, and landlord and tenant laws were the core knowledge required by real estate employees in Nigeria and the United Kingdom, respectively. Out of the $34 \mathrm{KS}$ items, 14 were found to have RI values of greater than 0.80 , thus indicating that these items were perceived by employers as the most important knowledge and skills for their employees.

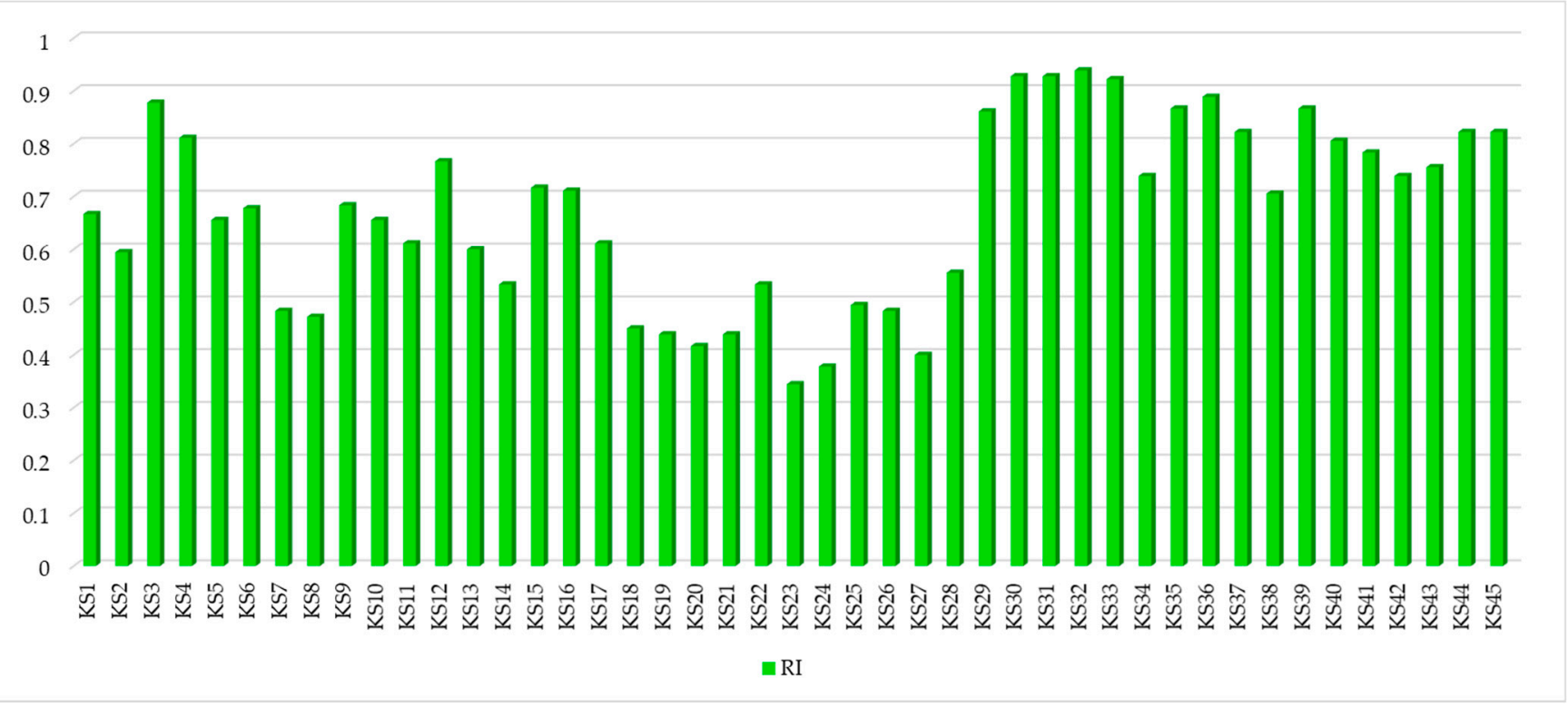

Figure 1. Perceived importance of knowledge and skills according to property employers based on RI.

In this study, it was found that 'Problem solving' $(K S 32 ; \mathrm{RI}=0.94 ;$ WRS statistic $=5.425)$ was highly regarded as the most important skill by most employers, followed by 'Report writing' $(K S 30 ;$ RI = 0.93; WRS statistic $=5.340)$, 'Numeracy' $(K S 31 ;$ RI = 0.93; WRS statistic $=5.340),{ }^{\prime}$ Negotiation' $(K S 33, \mathrm{RI}=0.93 ;$ WRS statistic $=5.304)$, 'Microsoft office Suite' (KS36; RI = 0.89; WRS statistic $=5.121)^{\prime}$, 'Professional ethics' (KS3; RI = 0.88; WRS statistic $=4.553)$, 'Critical thinking' $(\mathrm{KS} 35 ; \mathrm{RI}=0.87$; WRS statistic $=5.015)$, 'Ability to work independently' (KS39; RI = 0.87; WRS statistic $=4.893)$, 'Effective writing communication' $(\mathrm{KS} 29 ; \mathrm{RI}=0.86$; WRS statistic $=4.593)$, 'Industry-based software' (KS37; RI = 0.82; WRS statistic $=4.211)$, 'Adaptability' $(\mathrm{KS} 44 ; \mathrm{RI}=0.82 ; \mathrm{WRS}$ statistic $=4.355)$, 'Emotional intelligence' $(\mathrm{KS} 45 ; \mathrm{RI}=0.82$; WRS statistic $=4.296)$, 'Customer service' $(\mathrm{KS} 4$; RI = 0.81; WRS statistic $=3.681)$, and 'Self-confidence' $(K S 40 ; R I=0.80 ;$ WRS statistic $=4.411)$. This tends to support the interview findings of Poon, Hoxley [71], who stated that graduate employees are not finished products and that their IT skills, written communication, numeracy, and report writing skills are critical enablers for their subsequent learning and development. Coupled with all these hard skills, they must be willing and determined to take on challenges and able to work and learn independently so that they can subsequently develop and improve their knowledge on property valuation and management and property law. In particular, Poon and Brownlow's [23] subsequent survey of Australian property professionals showed that valuation and practical experience are the most important knowledge areas and skillsets. Collectively, this could help explain why some of those 11 insignificant items were not found to be highly and collectively regarded by employer respondents.

These results also tend to add weight to the conclusions of Cooney [72] and Laurie [73], in that employees' negotiation skills are the key driver of effective stakeholder management, 
helping to reduce potential conflicts, achieve compromises among stakeholders, and hence obtain improved client satisfaction. Additionally, RICS [74] underlined that employees' written communication ability is the essence of the real estate and property sector, which is all about dealing with people and ensuring that messages are clear and professionally presented to all stakeholders involved. An overall picture that emerges here is that respondents tend to place equal emphasis on the importance of soft skills (KS32, KS33, KS35, KS39, KS40, KS44, and KS45) and hard skills (KS30, KS31, KS29, KS36, KS3, KS37, and KS4). Interestingly, this also reflects the market reality, where the constant increase in competition intensity has compelled employers to look for best hands who possess excellent hard and soft skills in order to remain viable in the changing business environment $[75,76]$. To this, Ismail, Yussof [77] added that, apart from having the necessary hard skillsets, property graduates need to possess creative and critical thinking, problem solving and analytical skills, and self-confidence in order to remain employable and thrive in the property sector.

Turning to the least important KS items, it is notable that KS23 'Sharing economy' $(\mathrm{RI}=0.34 ; \mathrm{WRS}=-4.855)$ and KS24 'Smart building $/$ city' $(\mathrm{RI}=0.38$; WRS = -4.469) were the only two items that were found within the range of 'low - medium' importance. Interestingly, these emerging knowledge bases have gained much attention among academics and practitioners within the property and real estate domain. To Baum, Saull [78], the rapid development and transformation of digital technologies have changed how transactions and communications take place among professionals, tenants, investors, and clients in the property sector. They added that, although real estate is not known as an industry that is ready to embrace change, it is worth mentioning that property professionals would need to slowly adapt to these changes in customers' expectations and behaviours towards smart buildings and a sharing economy, which could be defined as technology-based platforms that correspondingly facilitate the operation, management, and use of real estate assets within the context of a building or an entire city. In accepting the increasing importance of sharing economy, Sdino and Magoni [79] highlighted that there has been a major shift in the short-term housing-rental sector, spawning a new rental market fuelled by the increasing use of Airbnb, whereby short and very-short-term contracts can be established by the immediate and easily accessed encounter between demand and supply through the use of digital platforms. They added that the rental submarket has been considerably affected by the growth of the sharing economy, and that, when compared to traditional rentals, contracts are stipulated via Airbnb tend to offer lessors with much higher revenues and much lower restrictions. This phenomenon is further echoed by Huckle, Bhattacharya [80], who emphasised that the increasing focus on the Internet of Things and blockchain technologies has created decentralised and sharing economy applications that allow individuals to monetise and secure their assets to create more wealth. Notably, the respondents did not have a consensus on the importance of KS22 'blockchain' in this study. The overall picture that emerges here is that these dynamics could distort the traditional real estate market and affect the functions of property professionals and businesses. For example, property professionals should be aware of what type shared use is acceptable and the type of mechanisms that are compliance with the statutory and legal requirements of respective states.

Figure 2 articulates whether the knowledge and skills property graduates possess meet property employers' expectations. The results show that the performance of property graduates in Microsoft Office suite (above expectation by $13.9 \%$ of the respondents), selfconfidence $(11.1 \%)$, industry-based software $(8.3 \%)$, creativity $(5.6 \%)$, ability to work in a team $(5.6 \%)$, numeracy $(5.6 \%)$, effective oral communication $(5.6 \%)$, and property economics $(5.6 \%)$ is above property employers' expectations. None of these were ranked as the leading knowledge area or skill by property employers, except for numeracy and Microsoft Office Suite. This is generally echoed by the study of Galuppo and Worzala [11], in which technology and statistics were ranked as the least important. 


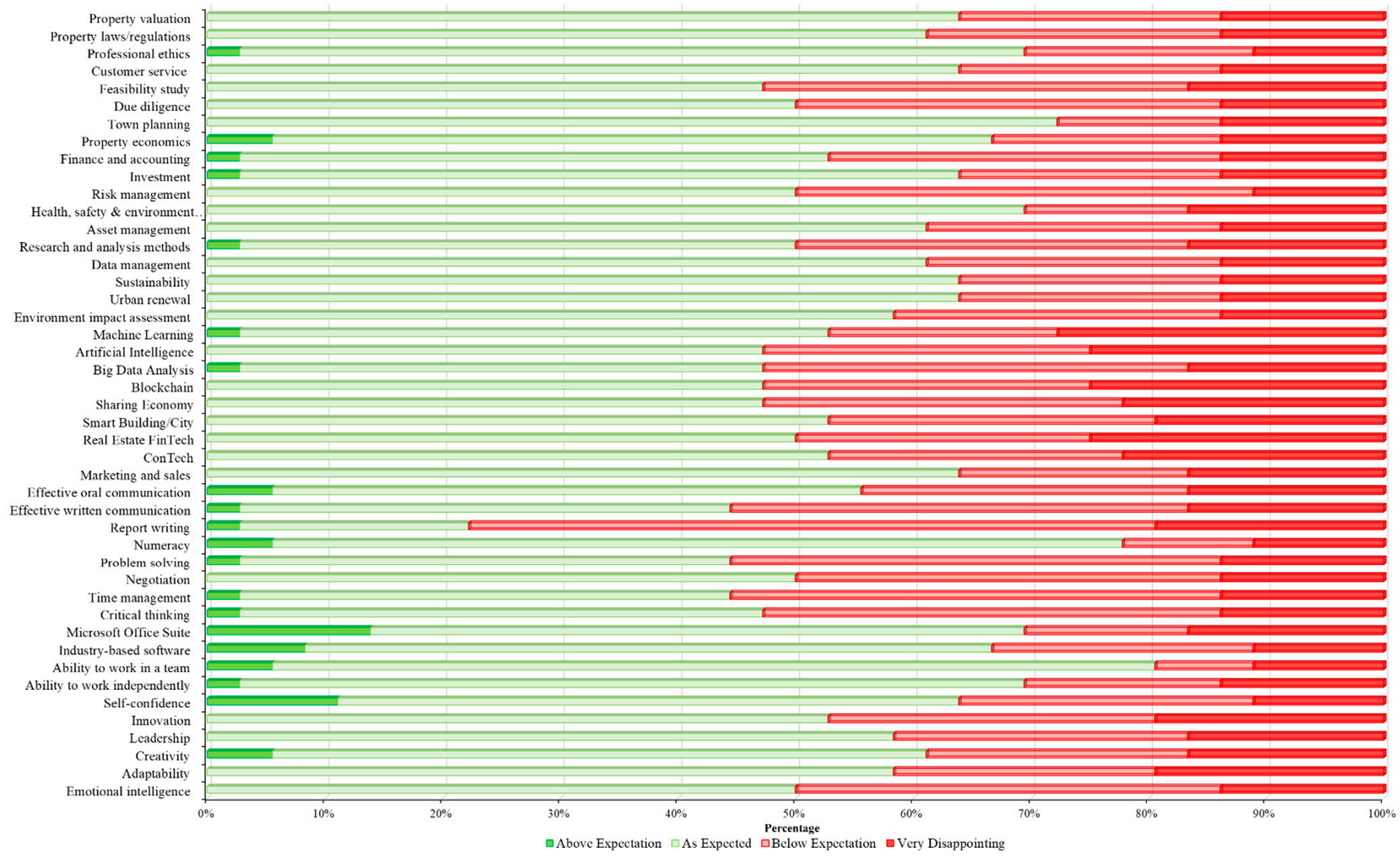

Figure 2. Expectations of property graduates' employers regarding the knowledge and skills possessed by property graduates.

Nevertheless, the property employers were disappointed at the practical performance of property graduates in machine learning (very disappointing by $27.8 \%$ of the respondents), artificial intelligence $(25.0 \%)$, blockchain $(25.0 \%)$, real estate FinTech $(22.2 \%)$, conTech $(22.2 \%)$, sharing economy $(22.2 \%)$, adaptability $(19.4 \%)$, innovation $(19.4 \%)$, report writing (19.4\%), smart buildings and cities (19.4\%), and town planning (19.4\%) (see Figure 2). In short, the property employers were disappointed at the performance of the property graduates in technology-related knowledge and skills. However, these sets were ranked as the least important knowledge and skills for property employers. This also reflects the findings of the study of Galuppo and Worzala [11], in which statistics and technology were rated as the least important. It is worth noting that report writing is one of the most important knowledge areas and skillsets for property employers. Nevertheless, the property employers in this study were not satisfied with the property graduates' performance.

Figure 3 summarises the degree of agreement among employer respondents regarding strategies for improving the knowledge and skills of graduates. Notably, all nine strategies were found to be statistically significant at $p<0.05$, with WRS statistics ranging from 2.122 to 5.321 . This suggests that there were general consensuses regarding the roles of these strategies in improving the knowledge and skills of property graduates. Of these, the respondents perceived that greater emphasis should be placed on designing school assessments based on real-life case studies $(\mathrm{S} 6 ; \mathrm{RI}=0.91)$, and that, to bridge the gap in expectation particularly with the assignment design, course directors should maintain close communication with employers $(\mathrm{S} 4 ; \mathrm{RI}=0.89)$. These tend to add weight to Galuppo and Worzala's [11] conclusion that the main expectation from real estate programs is to provide state-of the-art, high-quality and practical education as they will help foster the development of technical, social and technological skills of graduates. The findings also support Poon, Hoxley's [71] assertion that practitioners play a critical role in develop- 
ing students' commercial awareness by offering them real-life practical experience since universities could only provide students with simulated experience through field trips and academic projects as supplements to real-life practical experience. Furthermore, respondents strongly recognised that students should be encouraged to join professional organisations (S3; RI $=0.88$ ), as this could help build their network within the property social circle, thus improving their opportunity of gaining practical experience and employability. Interestingly, it was found that overhauling the university curriculums (S2) is one of the key strategies for improving students' knowledge and skillsets with an RI of 0.87 . Why respondents perceived such a need is not clear. Future studies should be conducted to further map the desired outcomes of property course curriculum and industry needs and expectations. Further strategies that are highly regarded by respondents include: inviting guest speakers from the industry to share their experience with students (S7; RI $=0.83$ ) and incorporating various methods such as simulation into course delivery (S5; RI $=0.8$ ). As Lateef [81] suggested, simulation is a technique for practice and learning that can be applied to help amplify real experiences with guided ones in a fully interactive fashion. Salamatina, Andronova's [82] application of training business simulation games in commercial property management showed that using simulation games can help to develop students' business acumen and commercial awareness and decision-making skills, as the students are often required to propose solutions for different scenario-based problems to address clients demand. In this study, the other strategy items (S1, S8, and S9) were found to have RIs of less than 0.8 , thus suggesting a 'high-medium' prevalence among respondents. Of these, it is not surprising that attending CPD as students is the lowest prioritised strategy, with an RI of 0.68; in particular, CPD programs are mainly designed to improve the knowledge base and skill of practitioners and experienced individuals rather than students lacking practical experience.

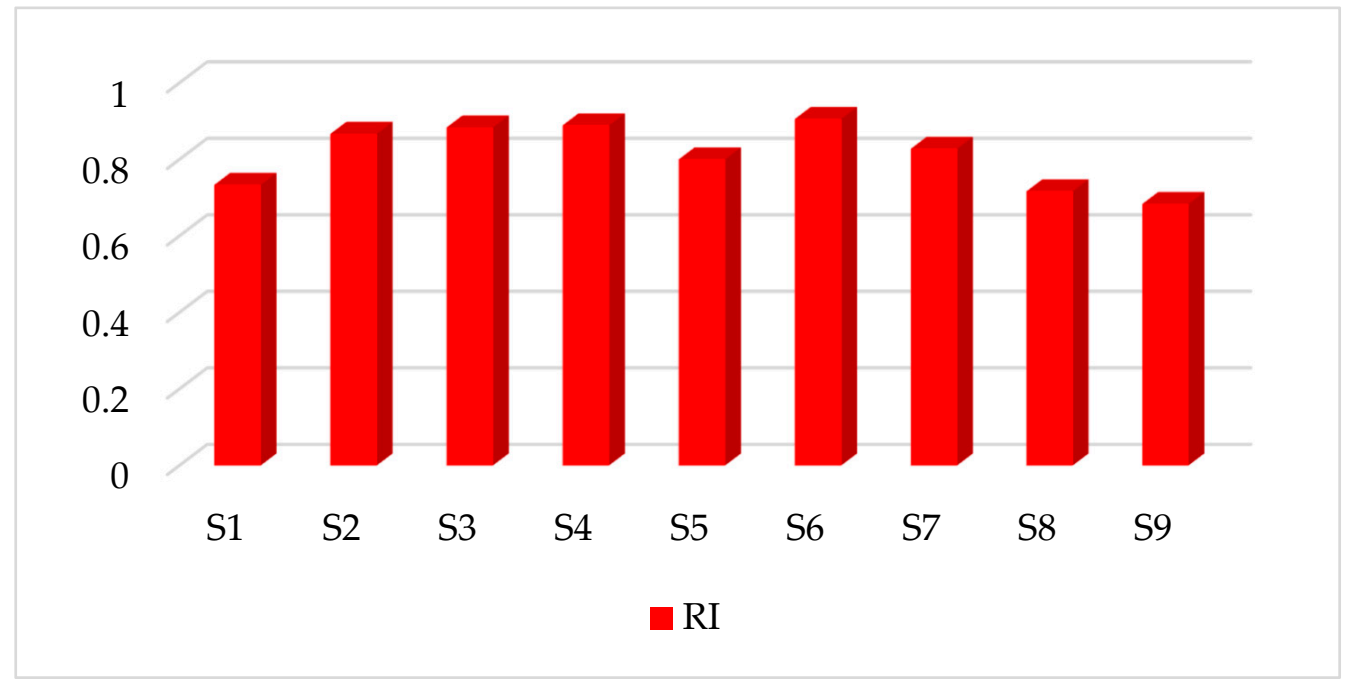

Figure 3. Property employers' opinions regarding ways to equip property graduates with the needed knowledge and skills.

\subsection{Profiles of the Property Graduates}

Table 3 shows the profiles of the property graduates sampled in this study. About $61.1 \%$ of the respondents had a bachelor's degree, while $38.9 \%$ of them had a postgraduate degree. In terms of the ages of the property graduates, $75.0 \%$ of our respondents were less than 30 years old, while $25 \%$ of them were 31 years old and above. The age distribution may reflect the fact that nearly $60.0 \%$ of the respondents had had less than five years of industry experience. On the other hand, around $40 \%$ of the property graduates had had more than five years of industry experience. Regarding the gender distribution of the respondents, $69.4 \%$ of the property graduates were males, while $30.6 \%$ of them were female. Table 3 
also presents the top five property specialisations of the property graduates. Construction project management was the top property specialisation for our respondents, followed by property development, construction, contract management, and property consultancy and analysis. Other specialisations included fund management, asset/facility management, and property valuation.

\subsection{Knowledge and Skills in the Digital Age for Property Graduates}

Figure 4 shows the perceived importance of those 45 knowledge and skills among the graduate respondents. Overall, the WRS test results showed that 32 out of the $45 \mathrm{KS}$ items were found to be statistically significant at $p<0.05$. This indicates that there were general consensuses regarding the importance of these 32 items among property graduates, while for the rest no collectively consensus was reached. The 13 items include KS1 'Property valuation', KS2 'Property laws', KS7 'Town planning', KS8 'Property economics', KS9 'Finance and accounting', KS10 'Investment', KS13 'Asset management', KS14 'Research and analysis methods', KS16 'Sustainability', KS17 'Urban renewal', KS18 'Environment impact assessment', KS24 'Smart building/city', and KS27 'Marketing and sales'. Interestingly, these items tend to relate to the knowledge bases rather than the soft skillsets of graduates. Furthermore, a similar trend has been noted between the perception of both graduates and employers, where KS1, KS2, KS10, KS13, KS14, KS1,7 and KS24 were found to be regarded as insignificant among them.

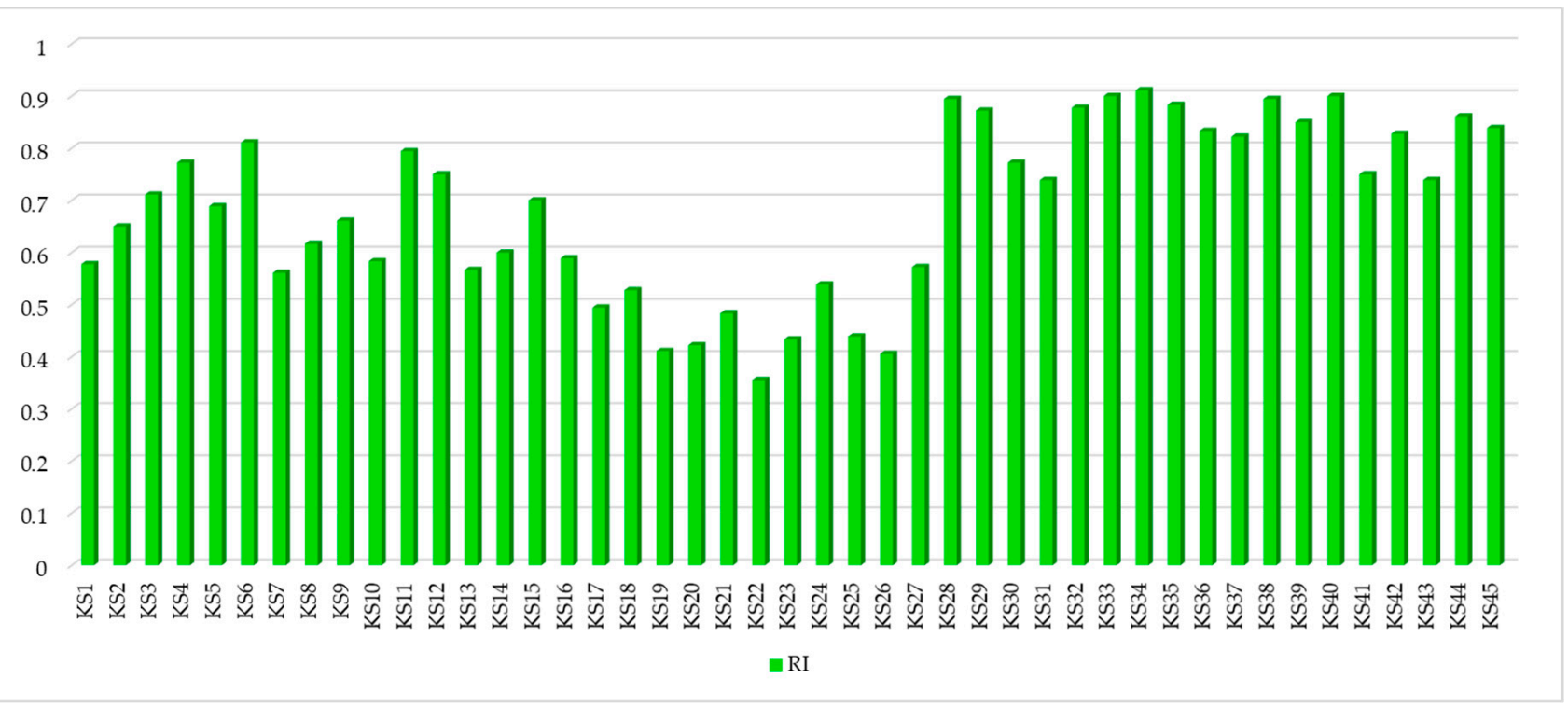

Figure 4. Significance of knowledge and skills according to property graduates based on R1.

From the graduates' perspective, time management (KS34; RI $=0.91)$, negotiation $(\mathrm{KS} 33 ; \mathrm{RI}=0.90)$, and self confidence $(\mathrm{KS} 40 ; \mathrm{RI}=0.90)$ were the top three priorities. These are indeed contradictory to the top three priorities of employers, in which graduates' key priorities are self-efficiency, while employers are work abilities. The finding tends to support Spellman's [83] assertion that determination and effective time management are essential drivers of a successful career progression for graduates. The author highlighted that effective time management will help graduates or entry-level employees to gain control over their work and progression by increasing their efficiency; improving their work-life balance; and, more importantly, enabling them to better cope with unforeseen problems that may arise from work or demands from their employers. This phenomenon is substantiated by Provencher and Keyes [84] and Zaheer, Ajayi [85], who claimed that there are positive significant correlations with graduates' time management skills and their ability to cope with culture shock and work stress. Interestingly, as White [86] and Karabay, Akyüz [87] 
suggested, individuals' self-confidence is associated with the courage required to assuring themselves about their time management and negotiation competencies, as well as other goal-setting values. Added to these, graduates perceived that it is essential for them or entry-level employees to possess an excellent ability to work in a team (KS38; RI $=0.89$ ); effective oral communication (KS28; RI =0.89); critical thinking skills (KS35; RI =0.88); problem solving skills (KS32; RI = 0.88); effective written communication $(\mathrm{KS} 29 ; \mathrm{RI}=0.87)$; adaptability (KS44; RI = 0.86); ability to work independently (KS39; RI = 0.85); high emotional intelligence $(\mathrm{KS} 45 ; \mathrm{RI}=0.84)$; knowledge on Microsoft Office Suite (KS36; RI = 0.83); leadership (KS42; RI =0.83); knowledge based software $(\mathrm{KS} 37 ; \mathrm{RI}=0.82)$; and due diligence $(\mathrm{KS6} ; \mathrm{RI}=0.811)$. From here, it seems that graduates and employers did share certain levels of perceived importance for KS29, KS35, KS36, KS37, KS39, KS44, and KS45. These could thus help inform academics and course conveners of the essential skillsets and knowledge areas that they could focus on in order to improve their students' employability and job readiness. At the other end, gaps were noted between graduates and employers, whereby the former highly rated the importance of KS38, KS28, KS42, and KS6, while the latter highly rated the importance of KS30, KS31, KS3, and KS4. The overall picture that emerges from here is that graduates tend to focus on their career development and progression, while employers emphasise graduates' work performance and contribution to their company's performance and operation. This is an interesting phenomenon that requires a balancing act between two parties for mutual benefits-particularly the employee-employer relationship, which may evolve and be fuelled by opportunities and challenges, and their expectations may have changed during the post-COVID-19 environment, as suggested by Volini, Schwartz [88].

Next, it is notable that knowledge of blockchain (KS22) is the only KS item, which graduates perceive to be of lower importance, with an RI of 0.36 . This somehow coincides with employers' perceived importance of Sharing Economy (KS23) and Smart Buildings (KS24), as discussed above. This result is not surprising considering the current implementation status and knowledge of blockchain in the Australian property market, and that there are numerous legal barriers to using blockchain technology for land title registry (see Practical Law 2018).

Figure 5 reflects the percentage of the knowledge areas and skills acquired by property graduates while in school. Over $25 \%$ of the property graduates indicated that selfconfidence, the ability to work in a team, critical thinking, the ability to work independently, time management, report writing, effective written communication, and effective research and analysis methods were strongly encouraged (80-100\%) at the university. Specifically, report writing and effective written communication were in the best and third place our of the knowledge areas and skills firmly acquired by the property graduates. This is exceptionally important for property employers too, who ranked report writing and effective written communication as the second and third most important knowledge areas and skills in this study. This finding aligns with that of Galuppo and Worzala [11], Callanan and McCarthy [19], Weinstein and Worzala [14], Poon [33], and Xiao and Chan [4].

However, on average $77.1 \%$ of the property graduates rated negotiation, marketing and sales, conTech, real estate FinTech, smart building and city, sharing economy, blockchain, big data analysis, artificial intelligence, machine learning, environment impact assessment and urban renewal, asset management, financial accounting, town planning, and customer service as knowledge and skills that were less encouraged at the university. This is even though these technology-related data science analyses play a critical role in ascertaining social and technical phenomena in the digital age [24,54]. 


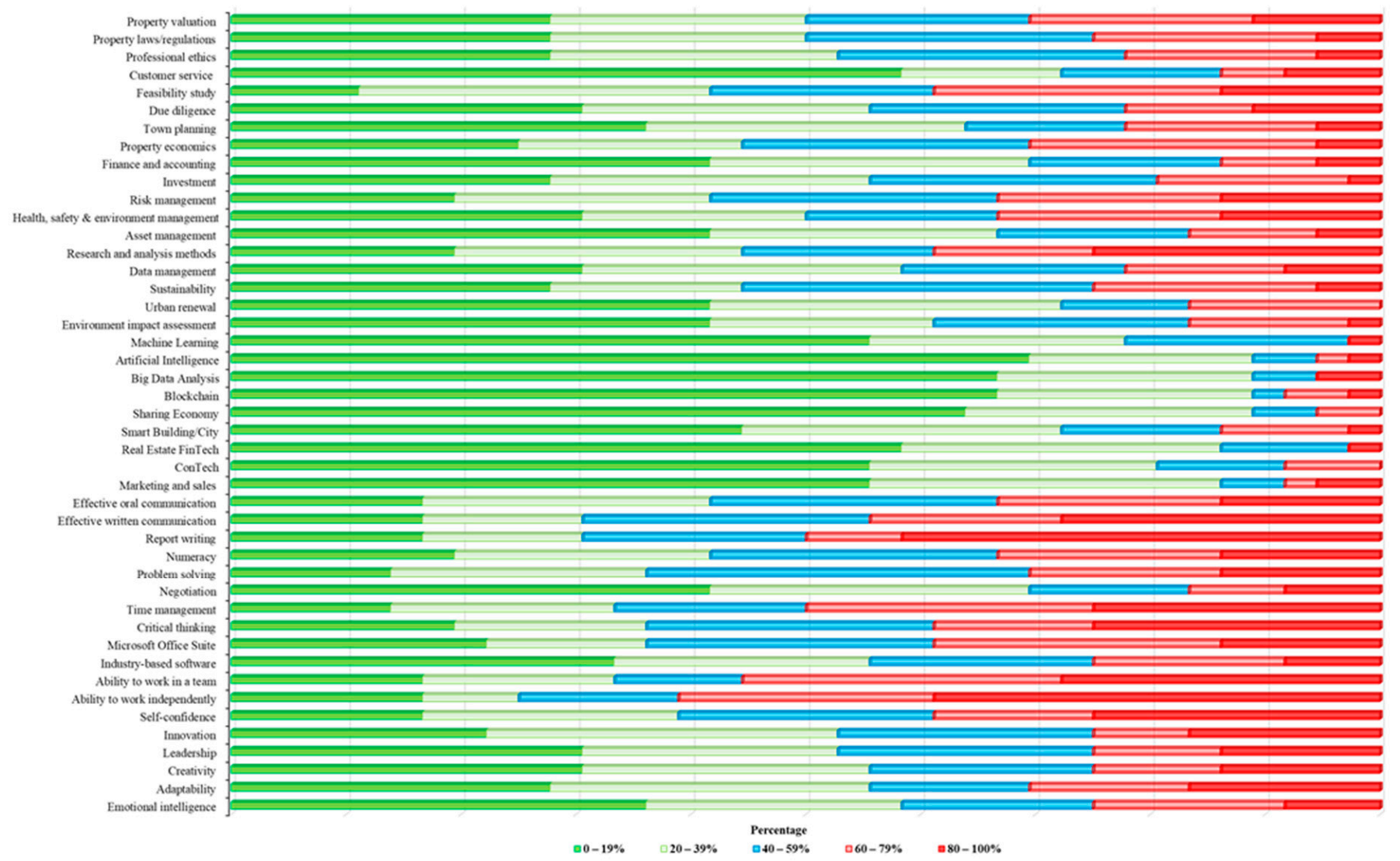

Figure 5. Knowledge and skills acquired by property graduates at the university.

Figure 6 shows graduates' perceived levels of agreement (based on RI) regarding the appropriateness of these nine strategies for improving their knowledge and skillsets. The overall WRS test results reveal that, out of the nine strategies, one was statistically insignificant, thus suggesting that graduates did not have a consensus regarding the appropriateness of S4, 'having close communication between course directors and employers', which had an RI of 0.65 (lowest of all items). This, therefore, contradicts the results gained for employers, who chose $\mathrm{S} 4$ as the 2nd most prioritised strategy. Indeed, six of the eight strategies had an RI above 0.8 -i.e., within the range of 'High' prevalence. Sadly, overhauling university curriculum $(S 2 ; \mathrm{RI}=0.90$; WRS statistic $=4.929)$ was thought of highly by graduates, followed by having guest speakers from the industry $(\mathrm{S} 7 ; \mathrm{RI}=0.89$; WRS statistic $=4.871)$, having various different course delivery methods ( $S 5 ; \mathrm{RI}=0.88$; WRS statistics $=4.509$ ), encouraging students to join professional bodies $(\mathrm{S} 3 ; \mathrm{RI}=0.85$; WRS statistics $=4.699)$, having compulsory internship training while studying $(S 8 ; \mathrm{RI}=0.83$; WRS statistics $=3.873)$, and incorporating real-life case studies into assignments $(\mathrm{S} 6 ; \mathrm{RI}=0.81$; WRS statistics $=3.843$ ). It is not clear why graduates perceived the need to overhaul the university property-related curriculum. Future attempts should be considered to explore why there is a need for this and how property-related curricula could be much updated and better aligned with the expectations of both graduates and employers. This tends to reflect the findings of Abidoye and Chan [89], who stated that overhauling the curricula of higher institutions of learning in Nigeria is essential for the better adoption and inclusion of AI techniques and modules into relevant courses. In this study, evidence also points toward the need to further and better incorporate real-life case simulations and experience sharing into course delivery, as demonstrated by the employers' and graduates' perceptions of S3, S5, and S7. Interestingly, it also seems that these two groups of respondents did not much appreciate the strategies used for on-the-job training after graduation (S1) and attending CPD as students (S9), with respective RIs ranging from 0.68 to 0.77 , when compared to those strategies. Collectively, 
the results shed light on the increasing emphasis on work-integrated learning and students early entry and transition into the workforce in order to gain practical experience. As Stephanie [90] highlighted, university study is far more than just earning a degree and also concerns preparing students for the world of employment before or after their graduation. Therefore, it is important for academia and industry to collaborate and set up bespoke job roles for students to allow them to gain invaluable workplace experience and apply what they have learnt in their studies on the job.

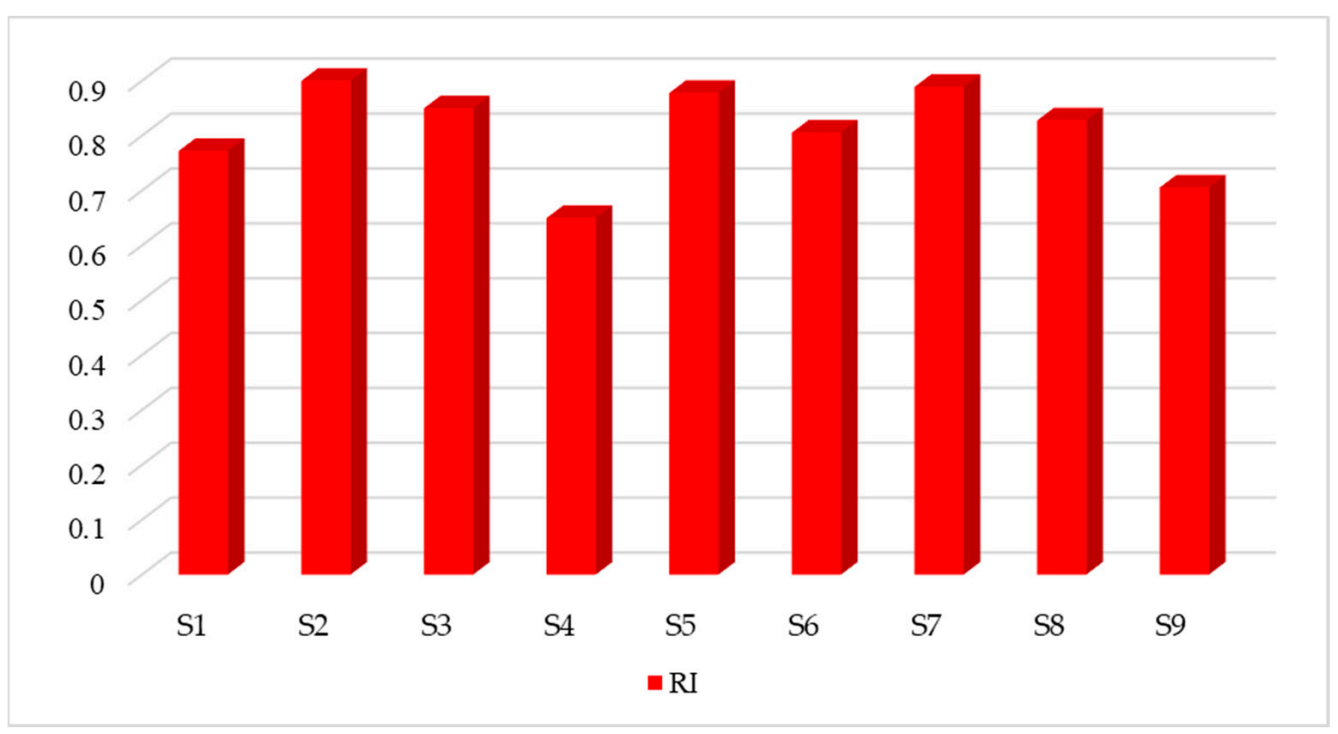

Figure 6. Opinions of property graduates regarding ways to acquire listed knowledge and skills.

\subsection{Differences in Perceived Importance of Knowledge and Skills between Employers and Graduates}

Table 4 summarises the Mann-Whitney $U$ test results for the significant differences in the perceived importance of knowledge and skills between employers and graduates. Overall, the test results revealed that 15 out of the $45 \mathrm{KS}$ items were statistically significant at $p<0.05$. This indicates that there were significant differences in those 15 items between employers and graduates. Notably, employers attributed a higher level of perceived importance to the knowledge of professional ethics (KS3), sustainability (KS16), blockchain (KS22), and the skills of report writing (KS30) and numeracy (KS31) than graduates did. This could display an interesting industry trend concerning the increasing emphasis on sustainability, professional practices, and digital technology advancement. Employers expect graduates, apart from having good report writing and numeracy skills, to be aware of sustainability principles and practices and be familiar with the code of ethics and practices of a real estate professional before entering the workforce. This tends to add weight to the conclusions of Dziubaniuk and Nyholm [91], who stated that students should be exposed to information about sustainability and business ethics as early as possible in their university, considering that these knowledge and lessons could have a significant influence on their subsequent career paths, defining their ethical behaviours and perception and thus preparing them to be socially responsible professionals. At the other end, it is notable that graduates tended to place greater emphasis on soft skills than employers, focusing on due diligence (KS6), oral communication skills (KS28), time management skills (KS34), teamwork abilities (KS38), self-confidence (KS40), and leadership (KS42). This indeed points to the differences in the business and self-development orientations of employers and graduates, respectively, as previously discussed in Section 4.4. 
Table 4. Significant differences in the perceived importance of knowledge and skillsets.

\begin{tabular}{ccccc}
\hline Item Code & Employers & Graduates & \\
\hline \multicolumn{2}{c}{ Mean Rank } & MWU Test & Significance \\
\hline KS3 & 43.86 & 29.14 & 383.000 & 0.002 \\
KS6 & 30.68 & 42.32 & 438.500 & 0.014 \\
KS8 & 31.06 & 41.94 & 452.000 & 0.023 \\
KS11 & 28.28 & 44.72 & 352.000 & 0.001 \\
KS16 & 42.17 & 30.83 & 444.000 & 0.017 \\
KS22 & 43.53 & 29.47 & 395.000 & 0.003 \\
KS24 & 31.36 & 41.64 & 463.000 & 0.030 \\
KS27 & 30.99 & 42.01 & 449.500 & 0.019 \\
KS28 & 24.50 & 48.50 & 216.000 & 0.000 \\
KS30 & 42.21 & 30.79 & 442.500 & 0.009 \\
KS31 & 44.17 & 27.60 & 336.000 & 0.000 \\
KS34 & 28.39 & 44.61 & 356.000 & 0.000 \\
KS38 & 27.47 & 45.53 & 323.000 & 0.000 \\
KS40 & 30.03 & 42.97 & 415.000 & 0.004 \\
KS42 & 31.85 & 41.15 & 480.500 & 0.047 \\
\hline
\end{tabular}

NB: all insignificant items have been deleted.

\subsection{Differences in Perceived Strategies between Employers and Graduates}

Turning to the perceived strategies, the results in Table 5 show that, out of the nine strategies, five were found to be statistically significant at $p<0.05$. This means that employers and graduates did have different thoughts about how these strategies could help improve the knowledge and skills of students. Notably, employers tended to place greater emphasis on close communication and engagement between course directors and practitioners (S4) and incorporating real case studies into assignments (S6) than graduates did. This perhaps points to the reality that there is a serious lack of engagement, communication, and understanding between academics and industry practitioners, as noted by Patrick, Heazlett [92], while Evans and Plewa [93] highlighted that the stakes for academic and industry collaboration in Australia are increasingly high and that universities are under more pressure than ever to collaborate with industry in order to improve their education level, meet increasing societal expectations, and bridge the gap between practicalities and expectations to achieve the sustainable growth of the future workforce. On the other hand, it was found that graduates showed stronger support for the use of various course delivery methods (S5), inviting guest speakers (S7), and promoting compulsory internship training while studying for students (S8) than employers did. One possible explanation for this is that graduates highly rate the importance of students being exposed to the real-life business environment as early as possible through real-life business simulations as well as the experience sharing of industry speakers. In particular, as highlighted by Carr [94], students should consider planning and setting up their graduate careers as early as their first year at university in order to minimise culture shock and improve their employability. The author added that, by involving themselves in different curriculum activities and social networking events, students could develop their soft skillsets (such as critical thinking, problem solving, creativity, adaptability, and social and cultural awareness). Furthermore, the author stated that if they could work as an intern and apply what they have learnt from their studies, this would help to improve their employability upon graduation.

Table 5. Significant differences in strategies.

\begin{tabular}{ccccc}
\hline Item Code & Employers & Graduates & \\
\hline \multicolumn{2}{c}{ Mean Rank } & MWU Test & Significance \\
\hline S4 & 43.61 & 29.39 & 392.000 & 0.002 \\
S5 & 29.81 & 43.19 & 407.000 & 0.003 \\
S6 & 41.54 & 31.46 & 466.500 & 0.025 \\
S7 & 32.07 & 40.93 & 488.500 & 0.049 \\
S8 & 29.67 & 43.33 & 402.000 & 0.004 \\
\hline
\end{tabular}

NB: all insignificant items have been deleted. 


\section{Conclusions}

This study aimed to assess the gaps in a range of knowledge and skills relevant to the property industry in the digital age from the perspectives of property graduates' employers and property graduates in Australia. The competencies identified in this research included 45 knowledge areas and skills. Several key findings were identified. Firstly, the most important knowledge area and skill for property employers was problem-solving. This can be explained by the backgrounds of the property employers used in this study. The majority of the respondents specialised in property consultancy and analysis and property valuation. These specialisations require professionals to solve problems when conducting market analyses for property consultancy and property valuations. The other most important knowledge and skill areas according to the property employers were report writing, numeracy, negotiation, Microsoft Office Suite skills, professional ethics, and critical thinking. In contrast, the most important knowledge and skill area according to property graduates was time management. The other most important knowledge and skill areas according to the property graduates were negotiation, self-confidence, the ability to work in a team, effective oral communication, critical thinking, problem solving, and effective written communication. It is worth noting that the five most important knowledge and skills areas according to the property graduates were not rated to be most important by the property employers, except for negotiation. This also indicates the gaps regarding the perceived importance of knowledge and skills between the property employers and property graduates in the digital age. Thirdly, both property employers and property graduates perceived and ranked knowledge of sharing economy, smart buildings/cities, and blockchain as of low importance to property graduates. Lastly, the difference in the perceived importance of property-related knowledge and skills in the digital age between the two groups was statistically tested for the first time. The two groups showed statistically significant differences in 15 out of the 45 knowledge and skill areas. This reveals that the employers place more importance on professional practice knowledge and skills, while graduates emphasise soft skills. Furthermore, from the perspective of the two groups, five of the examined strategies had statistically significant differences regarding acquiring property-related knowledge and skills, such as course directors maintaining close communication with employers, school assessments being based on real-life case studies, the use of various course delivery methods, inviting guest speakers, and promoting compulsory internship training while studying for students.

Overall, the findings of this study have several profound implications for property education. Firstly, this research offers significant insights regarding the knowledge and skillsets perceived to be most important by property employers and property graduates in Australia. Furthermore, the gaps in the 45 knowledge and skill areas and 9 strategies for acquiring property-related knowledge and skillsets between these two groups were statistically identified. Property education providers should consider including these nominated knowledge and skillsets in their curriculum development and redesign to ensure that graduates are work-ready. Secondly, Australian property employers are yet to embrace technology-related data science analysis. This is despite the fact that data science analyses have played a critical role in ascertaining social and technical phenomena in the digital age. Property course providers should also be aware of the need for future property graduates to have knowledge of the use of technology-related data science analysis methods to be used in the property industry. Few property employers and graduates responded to this survey; hence, when more data are available, the results of this study may be different. Future studies could examine specific knowledge areas and skills required by property employers in each property sector. These recommendations display the potential of future studies on property education issues. 


\begin{abstract}
Author Contributions: Conceptualisation, R.A. and B.T.H.L.; methodology, B.T.H.L., Y.-C.L. and R.A.; software, B.T.H.L. and Y.-C.L.; formal analysis, B.T.H.L. and Y.-C.L.; investigation, R.A., B.T.H.L., Y.-C.L. and J.M.; resources, R.A. and B.T.H.L.; data curation, B.T.H.L. and Y.-C.L.; writing-original draft preparation, J.M. and Y.-C.L.; writing-review and editing, R.A. and B.T.H.L.; supervision, R.A. and B.T.H.L.; funding acquisition, R.A. All authors have read and agreed to the published version of the manuscript.

Funding: This research was funded by UNSW School of Built Environment Early Career Research Grant, Grant Number PS63207, and the APC was funded by the same fund. Data Availability StatementNot applicable.

Institutional Review Board Statement: The study was conducted according to the guidelines of the National Statement on Ethical Conduct in Human Research (2007), and approved by the Human Research Advisory Panel (HREAP) of UNSW Sydney (HC No HC210322 and approved on 19 May 2021).

Informed Consent Statement: Informed consent was obtained from all subjects involved in the study.

Data Availability Statement: Not applicable.

Acknowledgments: The authors would like to thank all the respondents of this study-both the employers and the graduates. Also, the constructive comments of the anonymous reviewers are much appreciated. This paper is part of a research project that focuses on preparing property graduates to be job-ready in the digital age, from which other papers with a different objective/scope that share the same background and methodology will be published.
\end{abstract}

Conflicts of Interest: The authors declare no conflict of interest.

\title{
References
}

1. Giang, D.T.; Pheng, L.S. Role of construction in economic development: Review of key concepts in the past 40 years. Habitat Int. 2011, 35, 118-125. [CrossRef]

2. Property Council of Australia. Property Industry Now Australia's Biggest Employer. 2018. Available online: https: //www.propertycouncil.com.au/Web/Content/Media_Release/National/2018/Property_industry_now_Australia_s_biggest_ employer.aspx (accessed on 22 September 2021).

3. Abidoye, R.B.; Junge, M.; Lam, T.Y.M.; Oyedokun, T.B.; Tipping, M.L. Property valuation methods in practice: Evidence from Australia. Prop. Manag. 2019, 37, 701-718. [CrossRef]

4. Xiao, Y.; Chan, N. The dilemma and future of property valuation education in China. Pac. Rim Prop. Res. J. 2016, 22, 145-165. [CrossRef]

5. Newell, G.; Eves, C. Recent developments in property education in Australia. Aust. Prop. J. 2000, 36, $275-278$.

6. Amidu, A.R.; Aluko, B.T. Client influence on valuation: Perceptual analysis of the driving factors. Int. J. Strateg. Prop. Manag. 2007, 11, 77-89. [CrossRef]

7. Van de Ven, A.H.; Johnson, P.E. Knowledge for theory and practice. Acad. Manag. Rev. 2006, 31, 802-821. [CrossRef]

8. Shi-Ming, Y. New paradigms in real estate education. Pac. Rim Prop. Res. J. 2001, 7, 79-88. [CrossRef]

9. Gibler, K.; Black, R.; Moon, K. Time, place, space, technology and corporate real estate strategy. J. Real Estate Res. 2002, 24, 235-262. [CrossRef]

10. Epley, D. New ranking of decision-making subject areas for corporate real estate executives. J. Real Estate Res. 2004, 26, 43-68. [CrossRef]

11. Galuppo, L.; Worzala, E. A study into the important elements of a masters degree in real estate. J. Real Estate Pract. Educ. 2004, 7, 25-42. [CrossRef]

12. Warren, C.M.; Heng, S. FM Education are we meeting industry needs. In Proceedings of the Pacific Rim Real Estate Society Conference, Melbourne, VIC, Australia, 24-27 January 2005; Pacific Rim Real Estate Society: Brisbane, QLD, Australia, 2005.

13. Manning, C.; Epley, D. Do real estate faculty teach the skills and competencies needed by corporate real estate executives? J. Real Estate Pract. Educ. 2006, 9, 37-59.

14. Weinstein, M.; Worzala, E. Graduate real estate programs: An analysis of the past and present and trends for the future. J. Real Estate Lit. 2008, 16, 385-414. [CrossRef]

15. Poon, J. Examining graduate built environment student satisfaction in the UK. What matters the most? Int. J. Constr. Educ. Res. 2019, 15, 179-197. [CrossRef]

16. Amidu, A.; Ogbesoyen, O.; Agboola, A.O. Exploring gaps between real estate curriculum and industry needs: A mapping exercise. Pac. Rim Prop. Res. J. 2018, 24, 265-283. [CrossRef]

17. Mooya, M.M. The education and professional practice of valuers in South Africa: A critical review. Prop. Manag. 2015, 33, 245-274. [CrossRef]

18. Oladokun, T.T. An evaluation of the training needs of Nigerian estate surveyors for corporate real estate management practice. Prop. Manag. 2012, 30, 86-100. [CrossRef] 
19. Callanan, J.; McCarthy, I. Property education in New Zealand: Industry requirements and student perceptions. J. Real Estate Pract. Educ. 2003, 6, 23-32. [CrossRef]

20. Avdiev, R. Golden apple or poisoned chalice the influence of education on careers. Pac. Rim Prop. Res. J. 2000, 6, 3-5. [CrossRef]

21. Boyd, T. Stakeholder impact on property education programs. In Proceedings of the 11th Pacific Rim Real Estate Conference (PPRES), Melbourne, VIC, Australia, 24-27 January 2005; PRRES: Brisbane, QLD, Australia, 2005.

22. Blake, A.; Susilawati, C. An evaluation of how well undergraduate property students are prepared for commencing their careers. Pac. Rim Prop. Res. J. 2009, 15, 204-224. [CrossRef]

23. Poon, J.; Brownlow, M. Competency expectations for property professionals in Australia. J. Prop. Invest. Financ. 2014, 32, $256-281$. [CrossRef]

24. Daniel, B.K. Big Data and Learning Analytics in Higher Education: Current Theory and Practice; Springer: Cham, Switzerland, 2016; 271p.

25. Black, R.; Rabianski, J. Defining the real estate body of knowledge: A survey approach. J. Real Estate Pract. Educ. 2003, 6, 33-54. [CrossRef]

26. Yiu, M.; Law, R. A review of hospitality internship: Different perspectives of students, employers, and educators. J. Teach. Travel Tour. 2012, 12, 377-402. [CrossRef]

27. Succi, C.; Canovi, M. Soft skills to enhance graduate employability: Comparing students and employers' perceptions. Stud. High. Educ. 2020, 45, 1834-1847. [CrossRef]

28. Aliu, J.; Aigbavboa, C. Key generic skills for employability of built environment graduates. Int. J. Constr. Manag. 2021, 1-19. [CrossRef]

29. Torres-Machí, C.; Carrión García, A.; Yepes, V.; Pellicer, E. Employability of graduate students in construction management. J. Prof. Issues Eng. Educ. Pract. 2013, 139, 163-170. [CrossRef]

30. Devaney, S.; Roberts, D. Who gets the jobs? Factors influencing the employability of property and construction graduates in the UK. Constr. Manag. Econ. 2012, 30, 233-246. [CrossRef]

31. Ayodele, T.O.; Oladokun, T.T.; Kajimo-Shakantu, K. Employability skills of real estate graduates in Nigeria: A skill gap analysis. J. Facil. Manag. 2020, 18, 297-323. [CrossRef]

32. Hoxley, M.; Poon, J.; Fuchs, W. Real estate employability: Differing perceptions of graduates from undergraduate and postgraduate courses. J. Eur. Real Estate Res. 2011, 4, 243-258. [CrossRef]

33. Poon, J. Do real estate courses sufficiently develop graduates' employability skills? Perspectives from multiple stakeholders. Educ. Train. 2014, 56, 562-581. [CrossRef]

34. Blake, A.; Cradduck, L.; Richardson, K.; Eves, C. Real property law: Its place in Australian undergraduate real estate programs. J. Real Estate Pract. Educ. 2010, 13, 141-158. [CrossRef]

35. Alao, A.; Pilane, C.D.; Mabote, M.M.; Setlhare, K.; Mophuting, K.; Semphadile, K.M.; Odirile, L.W.; Kgathi, P.L.; Mmapatsi, S. Employer satisfaction survey of the University of Botswana graduates. Int. J. Contemp. Issues Educ. Psychol. 2009, 1, 17-34.

36. Matsouka, K.; Mihail, D.M. Graduates' employability: What do graduates and employers think? Ind. High. Educ. 2016, 30, 321-326. [CrossRef]

37. Obi, L.; Hampton, P.; Awuzie, B. Total Interpretive Structural Modelling of Graduate Employability Skills for the Built Environment Sector. Educ. Sci. 2020, 10, 369. [CrossRef]

38. Jackson, D.; Chapman, E. Non-technical skill gaps in Australian business graduates. Educ. Train. 2012, 54, 95-113. [CrossRef]

39. Prikshat, V.; Montague, A.; Connell, J.; Burgess, J. Australian graduates' work readiness-deficiencies, causes and potential solutions. High. Educ. Ski. Work Based Learn. 2019, 10, 369-386. [CrossRef]

40. Savage, S. Urban design education: Learning for life in practice. Urban Des. Int. 2005, 10, 3-10. [CrossRef]

41. Gallardo-Vázquez, D.; Folgado-Fernández, J.A. Regional economic sustainability: Universities' role in their Territories. Land 2020, 9, 102. [CrossRef]

42. Pate, D.L. The Skills Companies Need Most in 2020—and How to Learn Them. Available online: https://www.linkedin.com/ business/learning/blog/top-skills-and-courses/the-skills-companies-need-most-in-2020and-how-to-learn-them (accessed on 5 March 2020).

43. Starr, C.W.; Saginor, J.; Worzala, E. The rise of PropTech: Emerging industrial technologies and their impact on real estate. J. Prop. Invest. Financ. 2021, 39, 157-169. [CrossRef]

44. Baum, A. PropTech 3.0: The Future of Real Estate; University of Oxford: Oxford, UK, 2017.

45. Azmi, I.A.G.; Hashim, R.C.; Yusoff, Y.M. The employability skills of Malaysian university students. Int. J. Mod. Trends Soc. Sci. 2018, 1, 1-14.

46. Poon, J. Real estate graduates' employability skills: The perspective of human resource managers of surveying firms. Prop. Manag. 2012, 30, 416-434. [CrossRef]

47. Newell, G.; Mallik, G. The importance of mathematics background and student performance in a property degree. Pac. Rim Prop. Res. J. 2011, 17, 313-328. [CrossRef]

48. Reid, J.R.; Anderson, P.R. Critical thinking in the business classroom. J. Educ. Bus. 2012, 87, 52-59. [CrossRef]

49. Ahn, Y.H.; Annie, R.P.; Kwon, H. Key competencies for US construction graduates: Industry perspective. J. Prof. Issues Eng. Educ. Pract. 2012, 138, 123-130. [CrossRef]

50. Ndong de Sousa, P.N. Assessment of Quantity Surveying Curriculum Development in South Africa. Master's Dissertation, University of Johannesburg, Johannesburg, South Africa, 2013; 252p. 
51. Odubiyi, T.B.; Aghimien, D.; Aigbavboa, C.; Thwala, W. Bridging the gap between academic and practice Quantity Surveying in Nigerian construction industry. In Proceedings of the 2019 Modular and Offsite Construction (MOC) Summit, Banff, AB, Canada, 21-24 May 2019; Al-Hussein, M., Ed.; Univeristy of Alberta: Edmonton, AB, Canada, 2019.

52. Avramenko, A. Enhancing students' employability through business simulation. Educ. Train. 2012, 54, 355-367. [CrossRef]

53. Wong, J.M.; Wong, F.K.; Hui, E.C. A study to improve higher education for surveying professionals in Hong Kong. J. Educ. Built Environ. 2007, 2, 76-89. [CrossRef]

54. Scheurwater, S. The Future of Valuations; Report for Royal Institution of Chartered Surveyors; RICS: London, UK, 2017 ; pp. 23-25.

55. Yogeshwaran, G.; Perera, B.; Ariyachandra, M.M.F. Competencies expected of graduate quantity surveyors working in developing countries. J. Financ. Manag. Prop. Constr. 2018, 23, 202-220. [CrossRef]

56. Neuman, W.L. Social Research Methods: Qualitative and Quantitative Approaches, 7th ed.; Pearson: London, UK, 2014; 594p.

57. Bryman, A. Social Research Methods; Oxford University Press: Oxford, UK, 2016.

58. Akintoye, A.; Fitzgerald, E. A survey of current cost estimating practices in the UK. Constr. Manag. Econ. 2000, 18, 161-172. [CrossRef]

59. Ott, R.L.; Longnecker, M.T. An Introduction to Statistical Methods and Data Analysis; Cengage Learning: Boston, MA, USA, 2015; 1296p.

60. Finlay, P.N.; Tyler, S.B. The performance measurement of property investments. J. Prop. Valuat. Invest. 1991, 9, 295-312. [CrossRef]

61. Abidoye, R.B.; Chan, A.P. Hedonic valuation of real estate properties in Nigeria. J. Afr. Real Estate Res. $2018,3,122-140$.

62. Effiong, J.B. A comparative study of valuation variance and accuracy between Nigeria and UK. Int. Lett. Soc. Humanist. Sci. 2015, $57,94-105$.

63. Steinmetz, C.; Thompson, S.; Marshall, N. Surveying international university students: The case of the 5\% response rate. Issues Educ. Res. 2020, 30, 1105-1125.

64. Warren-Myers, G.; Cradduck, L. Physical and climate change-related risk identification in valuation practice: An Australian perspective. J. Prop. Invest. Financ. 2021. [CrossRef]

65. Hill, R. What sample size is "enough" in internet survey research. Interpers. Comput. Technol. Electron. J. 21st Century 1998, 6, 1-10.

66. Loosemore, M.; Lim, B.T.-H. Intra-organisational injustice in the construction industry. Eng. Constr. Archit. Manag. 2016, 23, 428-447. [CrossRef]

67. Loosemore, M.; Lim, B.T.-H.; Ling, F.; Zeng, H. A comparison of corporate social responsibility practices in the Singapore, Australia and New Zealand construction industries. J. Clean. Prod. 2018, 190, 149-159. [CrossRef]

68. Akadiri, O.P. Development of a Multi-Criteria Approach for the Selection of Sustainable Materials for Building Projects. Ph.D. Thesis, University of Wolverhampton, Wolverhampton, UK, 2011.

69. Wilkinson, S.; Halvitigala, D.; Antoniades, H. The future of the valuation profession: Shaping the strategic direction of the profession for 2030. In Proceedings of the 23rd Annual Pacific Rim Real Estate Society Conference, Sydney, NSW, Australia, 15-18 January 2017; Pacific Rim Real Estate Society: Brisbane, QLD, Australia, 2017.

70. Coyle, M.L. Future of Valuation. 2015. Available online: https://www.workingre.com/future-of-valuation2/ (accessed on 7 June 2018).

71. Poon, J.; Hoxley, M.; Fuchs, W. Real estate education: An investigation of multiple stakeholders. Prop. Manag. 2011, 29, 468-487. [CrossRef]

72. Cooney, C. Real estate's varied job skill requirements. The Sydney Morning Herald, 4 November 2014.

73. Laurie, M. The Art of Give and Take Negotiation in Property Management. Available online: https://www.buildium.com/blog/ negotiation-in-property-management/ (accessed on 18 November 2021).

74. RICS. Why Good Communication Skills Matter in Real Estate Industry. Available online: https://www.ricssbe.org/what-s-new / expert-talk/communication-skills-matter-in-real-estate/ (accessed on 19 November 2021)

75. Robles, M.M. Executive perceptions of the top 10 soft skills needed in today's workplace. Bus. Commun. Q. 2012, 75, 453-465. [CrossRef]

76. Oladokun, T.T.; Olaleye, A. Bridging skill gap in real estate education in Nigeria. Pac. Rim Prop. Res. J. 2018, 24, 17-34. [CrossRef]

77. Ismail, R.; Yussof, I.; Sieng, L.W. Employers' perceptions on graduates in Malaysian services sector. Int. Bus. Manag. 2011, 5, 184-193. [CrossRef]

78. Baum, A.; Saull, A.; Braesemann, F. Proptech 2020: The Future of Real Estate; University of Oxford: Oxford, UK, 2020 ; p. 11.

79. Sdino, L.; Magoni, S. The sharing economy and real estate market: The phenomenon of shared houses. In Smart and Sustainable Planning for Cities and Regions, Proceedings of SSPCR 2017, Bolzano, Italy, 22-24 March 2017; Bisello, A., Vettorato, D., Laconte, P., Costa, S., Eds.; Springer: Cham, Switzerland, 2017.

80. Huckle, S.; Bhattacharya, R.; White, M.; Beloff, N. Internet of things, blockchain and shared economy applications. Procedia Comput. Sci. 2016, 98, 461-466. [CrossRef]

81. Lateef, F. Simulation-based learning: Just like the real thing. J. Emerg. Trauma Shock 2010, 3, 348-352. [CrossRef] [PubMed]

82. Salamatina, A.; Andronova, A.; Alekseeva, I. Training business simulation same: Commercial property management in a competitive environment. IOP Conf. Ser. Mater. Sci. Eng. 2019, 481, 012054. [CrossRef]

83. Spellman, R. Time Manage Your Way to the Top. The Guardian, 8 September 2010.

84. Provencher, H.L.; Keyes, C.L. Complete mental health recovery: Bridging mental illness with positive mental health. J. Public Ment. Health 2011, 10, 57-69. [CrossRef] 
85. Zaheer, M.I.; Ajayi, S.O.; Zulu, S.L.; Oyegoke, A.; Kazemi, H. Understanding the key competencies of market-ready building surveying graduates from employers' perspectives. J. Eng. Des. Technol. 2020, 19, 291-314. [CrossRef]

86. White, K.A. Self-confidence: A concept analysis. Nurs. Forum 2009, 44, 103-114. [CrossRef]

87. Karabay, M.E.; Akyüz, B.; Elçi, M. Effects of family-work conflict, locus of control, self confidence and extraversion personality on employee work stress. Procedia Soc. Behav. Sci. 2016, 235, 269-280. [CrossRef]

88. Volini, E.; Eaton, K.; Mallon, D.; Van Durme, Y.; Hauptmann, M.; Scoble-Williams, N.; Poynton, S.; The Worker-Employer Relationship Disrupted. If We're Not a Family, What Are We? Available online: https:/ /www2.deloitte.com/us/en/insights/ focus/human-capital-trends/2021/the-evolving-employer-employee-relationship.html (accessed on 19 November 2021).

89. Abidoye, R.B.; Chan, A.P.C. Valuers' receptiveness to the application of artificial intelligence in property valuation. Pac. Rim Prop. Res. J. 2017, 23, 175-193. [CrossRef]

90. Lukins, S. 9 Fantastic Benefits Work Integrated Learning. Available online: https://www.topuniversities.com/student-info/ careers-advice/9-fantastic-benefits-work-integrated-learning (accessed on 19 November 2021).

91. Dziubaniuk, O.; Nyholm, M. Constructivist approach in teaching sustainability and business ethics: A case study. Int. J. Sustain. High. Educ. 2020, 22, 177-197. [CrossRef]

92. Patrick, E.; Heazlett, D.; Anderson, J.; Hartley, V. Key for Successful Industry-Education Engagement; Mercer Consulting: Sydney, NSW, Australia, 2019; 30p.

93. Evans, D.; Plewa, C. Academics Do Want to Engage with Business, but Need More Support. Available online: https: / theconversation. com/academics-do-want-to-engage-with-business-but-need-more-support-62902 (accessed on 19 November 2021).

94. Carr, J. 10 Essential Career Tips for First-Year University Students. Available online: https://gradaustralia.com.au/careerplanning/10-essential-career-tips-for-first-year-university-students (accessed on 19 November 2021). 